\title{
Oceans need protection from scientists too
}

\section{Unregulated research poses a serious threat to some unique marine environments.}

Sir - Your News Feature "Sink or swim" (Nature 432, 12-14; 2004) reports that "conservation biologists generally agree" that unique marine habitats in the open sea require urgent protection. I assume that they mean from everyone except scientists. But academics also need to consider conservation when they plan research expeditions.

In 1994, as a PhD student participating in a British-Russian joint expedition to investigate the Trans-Atlantic Geotraverse hydrothermal vent site, I became concerned about the effects that scientific expeditions were having on these unusual habitats. My primary concern was that disturbance by submarines could be having unknown effects on the spectacular populations of endemic shrimp found around vent sites. My worries were later confirmed by the work of several colleagues who reported changes to the eyes of deep-sea vent shrimps caused by submersible illumination (P. J. Herring, E. Gaten and P. M. J. Shelton Nature 398, 116; 1999).

I spoke to a number of deep-sea biologists about my concerns and found many who agreed that better control and coordination of research expeditions was needed. Perhaps naively, I contacted a popular science magazine in the hope that I could start a campaign to embarrass the scientific establishment into better behaviour. Within a few days, a senior academic warned me that continuing to raise this issue would mean that I would probably never work in deep-sea science again and would be considered a firebrand rather than a serious scientist.

As an idealistic postgraduate, I found this response, and the lack of interest from the scientific press, disheartening.

Sadly, little has changed since then. In 2002, Canada identified Endeavour Hot Vents, off the country's pacific coast, as areas for official protection and conservation (see www.er.uqam.ca/nobel/oasis/act_2a. html). But after scientific groups raised concerns over freedom of access, officials at the Department of Fisheries and Oceans made it clear that it was their intention to encourage research at the site rather than restrict it.

The Worldwide Fund for Nature has recognized that one of the greatest threats to hydrothermal vents comes from 'uncoordinated and unregulated' research. When will scientists accept this fact?

Magnus Johnson

Scarborough Centre for Coastal Studies,

University of Hull, Filey Rd,

Scarborough YO11 3AZ, UK

\section{Oceans: fisheries not to blame for damage}

Sir - I was disappointed in your News Feature "Sink or swim" (Nature 432, 12-14; 2004), which mixes awe for the biological wonders of the sea and the excitement of new discoveries with concerns over the impact of human activities on the marine environment, in particular fishing.

Any link between the advancement of knowledge of ocean biodiversity and the impact of fisheries is at best tenuous. The News Feature does not present any quantitative evidence that fisheries are a threat to these newly discovered habitats. It largely seems to reflect a campaign run by a small group of scientists and some major non-governmental organizations.

The organization I work for, the North-East Atlantic Fisheries Commission (www.neafc.org), provides a forum for representatives of the major fisheries in the Northeast Atlantic to meet several times a year. They cooperate in fisheries management, control and enforcement by setting quotas and by closing vulnerable areas to fishing. As stipulated by the NEAFC Convention, this cooperation is based on the best available scientific evidence.

The Northeast Atlantic is probably one of the best-researched ocean areas in the world. A scientific organization, the International Council for the Exploration of the Sea, has coordinated research in the area for more than 100 years. It publishes on all aspects of the oceans, including the state of commercial fish species.
Your News Feature does not make use of the rich scientific literature on the Northeast Atlantic. Nor does it use information in the public domain about the major efforts made by fisheries and ocean managers to shape a framework for responsible human activities. I can assure you that managers want very much to be in the vanguard, both in rational utilization and ecological concerns.

As a biologist, I am thrilled by recent advances in scientific knowledge of the biodiversity of the oceans and habitats such as carbonate mounds, oceanic ridges with hydrothermal effects, seamounts and so on.

However, this feeling of elation should not be misused to campaign against the legitimate right to plan, develop and manage fisheries in a way that addresses the multiple needs and desires of society. Kjartan Hoydal

North-East Atlantic Fisheries Commission, 22 Berners Street, London W1T 3DY, UK

\section{No political interference in US agricultural grants}

Sir - I write on behalf of several former chief scientists in charge of the US Department of Agriculture's National Research Initiative (NRI) competitive grants programme. We wish to clarify part of your Editorial "A chance for growth" (Nature 432, 257; 2004).

The Editorial could be interpreted as suggesting that the department's competitive peer-reviewed research programmes are influenced by political interests. Such interests have played a part in dictating the general areas in which to conduct research, but as chief scientists in the competitive programmes area, we did not observe interference with the peerreview process itself.

The budget provided to the agriculture department for the NRI results, of course, from a political process. But the NRI review process is strictly based on scientific peer review with careful attention to conflicts of interest, appropriate representation and so on. The awarding of grants can be fully documented on the basis of rankings provided by the peer-review panels.

The peer-review process has been fair, thorough and equitable. In fact, an external review of the NRI - National Research Initiative: A Vital Competitive Grants Program in Food, Fiber and NaturalResources Research, published by the National Academies Press in 2000 indicated that its review process was more stringent than those in sister agencies.

It is accurate to say that noncompetitive grants, or earmarks, are commonly mandated by Congress. But these are not to be confused with competitive, peer-reviewed programmes. The Department of Agriculture is a complex agency and Congress dictates the boundaries of its purview.

\section{Anne Vidaver}

Department of Plant Pathology, 406 Plant Sciences, University of Nebraska, Lincoln, Nebraska 68583-0722, USA 